\title{
PERBANDINGAN KEMAMPUAN PEMECAHAN MASALAH MATEMATIS MELALUI MODEL PEMBELAJARAN PROBLEM BASED LEARNING (PBL) DAN MODEL PEMBELAJARAN LANGSUNG PADA SISWA KELAS VIII SMP N 22 BATANGHARI
}

\author{
Diana Aprianti ${ }^{1}$, Harman $^{2}$, Ayu Yarmayani $^{3}$ \\ Program Studi Pendidikan Matematika, FKIP, Universitas Batanghari ${ }^{1,2,3}$ \\ Jl. Slamet Riyadi No.1 Broni Jambi \\ Email: dianalah04@gmail.com
}

\begin{abstract}
ABSTRAK
Penelitian ini bertujuan untuk mengetahui perbandingan rata-rata hasil Post-test siswa yang menerapkan Model pembelajaran Problem Based Learning (PBL) dan Model Pembelajaran Langsung.Jenis Penelitian ini merupakan quasy eksperimen.Populasi dalam penelitian ini adalah seluruh kelas VIII SMP Negeri 22 Batanghari Tahun Ajaran 2017/2018.Pengambilan sampel menggunakan simple random sampling sedangkan sampel penelitian yang terambil adalah kelas VIII B dan VIII C. dimana dua kelas sampel ini diberikan perlakuan yang berbeda. Dari hasil penelitian yang dilakukan nilai rata-rata untuk kelas Eksperimen adalah 76,92 dengan simpangan baku 14,42 dan kelas kontrol rataratanya adalah 67,93 dengan simpangan baku 10,60. Serta dari hasil uji Hipotesisnya

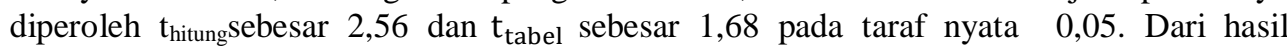
perhitungan itu terlihat bahwa $t_{\text {hitung }}$ lebih bsar dari $t_{\text {tabel }}$ maka $\mathrm{H}_{1}$ diterima. Berdasarkan hasil akhir dapat disimpulkan bahwa kemampuan pemecahan masalah matematika siswa yang menggunakanModel pembelajaran Problem Based Learning (PBL) lebih tinggi dari pada siswa yang menggunakan Model Pembelajaran Langsung pada siswa kelas VIII SMPN 22 Batanghari.
\end{abstract}

\section{Kata Kunci:}

Kemampuan Pemecahan Masalah Matematis, Model Pembelajaran Problem Based Learning (PBL)

\begin{abstract}
This study aims to determine the average comparison of the results of the Post-test of students who apply the Problem Based Learning (PBL) learning model and the Direct Learning Model. This type of research is a quasy experiment. 2017 / 2018. Sampling uses simple random sampling while the research sample taken is class VIII B and VIII C. where the two classes of samples are given different treatments. From the results of the study conducted an average value for the Experiment class was 76.92 with a standard deviation of 14.42 and the average control class was 67.93 with a standard deviation of 10.60. And from the Hypothesis test results obtained a tcount of 2.56 and a table of 1.68 at a significant level of 0.05. The calculation shows that tcount is greater than ttable, then HI is accepted. Based on the final results it can be concluded that the mathematical problem solving ability of students who use Problem Based Learning (PBL) learning models is higher than students who use the Direct Learning Model in class VIII students of SMPN 22 Batanghari.
\end{abstract}

\section{Keywords:}

Mathematical Problem Solving Ability, Problem Based Learning (PBL) Learning Model

\section{PENDAHULUAN}

Matematika merupakan bidang studi yang dipelajari oleh semua siswa dari SD sampai Perguruan Tinggi.Ada banyak alasan tentang perlunya siswa belajar matematika. Seperti yang tertuang dalam Undang-Undang Nomor 20 tahun 2003 tentang Sistem 


\section{$\pi$ (Phi)}

Pendidikan Nasional Pasal 37 Ayat 1 yang menyatakan bahwa kurikulum pendidikan dasar dan menengah wajib memuat: pendidikan agama, pendidikan kewarganegaraan, bahasa, matematika, ilmu pengetahuan alam, ilmu pengetahuan sosial, seni dan budaya, pendidikan jasmani dan olahraga, keterampilan/kejuruan, dan muatan lokal (Undang- undang Sistem Pendidikan Nasional, 2011). Undangundang tersebut semakin menegaskan bahwa matematika merupakan mata pelajaran wajib yang diajarkan sejak jenjang pendidikan dasar sampai menengah.Suatu mata pelajaran yang diharapkan mampu mempunyai kegunaan dalam kehidupan sehari-hari bagi yang mempelajarinya.

Menurut Cornelius (Abdurrahman: 2003) lima alasan perlunya belajar matematika karena matematika merupakan: (1) sarana berpikir yang jelas dan logis, (2) sarana untuk memecahkan masalah kehidupan sehari-hari, (3) sarana mengenal polapola hubungan dan generalisasi pengalaman, (4) sarana untuk mengembangkan kreativitas, dan (5) sarana untuk meningkatkan kesadaran terhadap perkembangan budaya.

Tujuan pembelajaran matematika yang dirumuskan oleh National Council of Teacher of Mathematics (2000) yaitu: (1) belajar untuk berkomunikasi (mathematical comminication), (2) belajar untuk bernalar (mathematical reasoning), (3) belajar untuk memecahkan masalah (mathematical problem solving), (4) belajar untuk mengaitkan ide (mathematical connections), (5) pembentukan sikap positif terhadap matematika (positive attitudes toward mathematics). Sesuai dengan tujuan pembelajaran matemtika yaitu salah satunya adalah untuk memecahkan masalah yang berhubungan dengan kehidupan seharihari.

Kemampuan pemecahan masalah matematis merupakan kemampuan dimana siswa berupaya mencari jalan keluar yang dilakukan dalam mencapai tujuan, juga merupakan kesiapan, kreativitas, pengetahuan dan kemapuan serta aplikasinya dalam kehidupan sehari-hari. Kemampuan pemecahan masalah matematis merupakan salah satu kemampuan yang harus dimiliki siswa, karena pemecahan masalah memberikan manfaat yang besar kepada siswa dalam melihat relevansi antara matematika dengan mata pelajaran lain, serta dalam kehidupan nyata

Model pembelajaran yang bercirikan adanya permasalahan nyata sebagi konteks untuk para peserta didik belajar berpikir kritis dan keterampilan memecahkan masalah serta memperoleh pengetahuan. Setiap proses dalam model pembelajaran Problem Based Learning (PBL) dapat digunakan untuk meningkatkan kemampuan pemecahan masalah siswa, seperti pada Learning is student-centered proses pembelajaran model Problem Based Learninng (PBL) lebih menitikberatkan kepada siswa sebagai seorang pelajar. Oleh karena itu, Problem Based Learninng (PBL) didukung juga oleh teori konstruktivisme dimana siswa di dorong untuk dapat mengebangkan pengetahuan sendiri.

Kelebihan pembelajaran dengan model problem based learninng (PBL) memiliki kemapuan membangun pengetahuannya sendiri melalui aktivitas belajar, terbiasa menggunakan sumber-sumber pengetahuan, baik dari 


\section{$\pi$ (Phi)}

perpustakaan, internet, wawancara, dan observasi. Karena untuk mencapai pemecahan masalah dituntut keaktifan belajar siswa yang lebih banyak. Dengan demikian pekerjaan belajar bagi seorang guru bukan sekedar menyelesaikan sejumlah materi pelajaran tetapi guru harus benar-benar mampu memecahkan masalah dengan harapan dapat dikuasai siswa.Adapun tujuan penelitian ini yaitu perbandingan kemampuan pemecahan masalah matematis melalui model pembelajaran Problem Based Learning (PBL) dan model pembelajaran langsung pada siswa kelas VIII SMP.

\section{METODE PENELITIAN}

Sesuai dengan permasalahan yang telah dikemukakan sebelumnya, maka Jenis penelitian yang digunakan dalam penelitian ini merupakan penelitian eksperimen. Menurut Sugiyono (2011:6), metode penelitian eksperimen merupakan metode penelitian yang digunakan untuk mencari pengaruh treatment (perlakuan) tertentu. Arikunto berpendapat (2013:9) "eksperimen adalah suatu cara untuk mencari hubungan sebab akibat (hubungan kausal) antara dua faktor yang sengaja ditimbulkan oleh peneliti dengan mengeliminisasi atau mengurangi atau menyisihkan faktor-faktor lain yang menganggu".

Penelitian ini dilakukan pada dua kelas yaitu kelas eksperimen dan kelas kontrol. Kelas eksperimen diajarkan dengan model pembelajaran problem based learning (PBL) dan kelas kontrol yang diajar dengan model pembelajaran langsung. Adapun penelitian ini menggunakan desain eksperimen. Desain eksperimen yang digunakan adalah postest only control design. Rancangan penelitian yang digunakan adalah sebagai berikut :

Tabel 1. Rancangan Penelitian

\begin{tabular}{ccc}
\hline Kelompok & Treatment & Post-Test \\
\hline Eksperimen & $\mathrm{X}$ & $\mathrm{O}_{1}$ \\
Kontrol & - & $\mathrm{O}_{2}$ \\
\hline
\end{tabular}

Instrumen dalam penelitian ini adalah berupa tes subjektif atau essay yang memenuhi kriteria validitas, tingkat kesukaran, daya beda dan realibilitas. Tes akhir (Post test) dilakukan setelah berakhirnya rangkaian pembelajaran pada kelas sampel.Teknik analisis data dalam penelitian ini adalah uji kesamaan dua rata-rata dengan asumsi data berdistribusi normal dan homogen. Sebelum melakukan pengujian hipotesis terlebih dahulu dilakukan dari data hasil postest perhitungan harga rata-rata hasil posttest, standar deviasi dan variansi, serta menguji apakah data berdistribusi normal dan homogeny. Uji normalitas yang dilakukan adalah uji chi-kuadrat (chi square).

Uji homogen varians bertujuan untuk mengetahui apakah kedua sampel memiliki varians yang homogen atau tidak.Uji hipotesis yang digunakan adalah uji kesamaan dua rata-rata. Uji ini digunakan untuk mengetahui kemampuan pemecahan masalah mana yang lebih baik antara siswa yang dibelajarkan menggunakan model pembelajaran problem based learning (PBL) dengan siswa yang dibelajarkan menggunakan model pembelajaran langsung. Pengujian kesamaan dua ratarata menggunakan uji t dengan hipotesis statistik: 
Jika data berdistribusi normal dan

maka digunakan uji-t dengan rumus: homogen, menurut Sudjana (2009:239)

$$
t_{\text {hitung }}=\frac{\bar{x}_{1}-\bar{x}_{2}}{S_{g a b} \sqrt{\frac{1}{n_{1}}+\frac{1}{n_{2}}}} \text { dengan } S^{2} g a b=\frac{\left(n_{1}-1\right) s^{2}{ }_{1}+\left(n_{2}-1\right) s^{2}}{n_{1}+n_{2}-2}
$$

Keterangan:

$\bar{x}_{1} \quad=$ Skor rata-rata Kemampuan pemecahan masalah matematis kelas eksperimen

$\bar{x}_{2} \quad=$ Skor rata-rata Kemampuan pemecahan masalah matematis kelas kontrol

$n_{1} \quad=$ Jumlah siswa kelas eksperimen

$n_{2} \quad=$ Jumlah siswa kelas kontrol

$s^{2}{ }_{1}=$ Variansi kelas eksperimen

$s_{2}^{2}=$ Variansi kelas kontrol

Dengan taraf signifikansinya $\alpha=$ 0,05 kriteria pengujiannya adalah terima $\mathrm{H}_{0}$ jika $\quad \mathrm{t}_{1}-\frac{1}{2}<\mathrm{t}<\mathrm{t}_{1}-\frac{1}{2} \alpha$, dimana $\mathrm{t}_{1}$ $\frac{1}{2} \alpha$ di dapat dari distribusi $\mathrm{t}$ dengan $\mathrm{dk}=$ $\left(\mathrm{n}_{1}+\mathrm{n}_{2}-2\right)$ dan peluang $\left(1-\frac{1}{2} \alpha\right)$. Untuk harga-harga t lainnya $\mathrm{H}_{0}$ ditolak.

\section{HASIL DAN PEMBAHASAN}

Hasil dari penelitian ini berupa uji normalitas, uji homogenitas, dan uji hipotesis. Menguji normalitas data hasil posttest kemampuan pemecahan masalah matematis siswa dikelas eksperimen dan kelas kontrol dapat di lihat pada tabel 2 di bawah ini:

Tabel 2. Uji Normalitas Kelas Sampel

\begin{tabular}{cccccc}
\hline Kelas Sampel & $\mathbf{N}$ & $\mathbf{X}^{2}{ }_{\text {hit }}$ & $\begin{array}{c}\mathbf{X}^{\mathbf{2}} \text { tab } \\
\mathbf{A = 5 \%}\end{array}$ & Hasil Uji & Ket \\
\hline Ekspeimen & 26 & 3,99 & 7,81 & $\mathrm{X}^{2}{ }_{\text {hit }}<\mathrm{X}^{2}$ tab & Normal \\
Kontrol & 26 & 2,97 & 7,81 & $\mathrm{X}^{2}{ }_{\text {hit }}<\mathrm{X}_{\text {tab }}$ & Normal \\
\hline
\end{tabular}

Berdasarkan keterangan perhitungan pada tabel $12 \mathrm{di}$ atas terlihat bahwa kedua kelas sampel mempunyai nilai $\mathrm{X}^{2}$ hitung lebih kecil dari $\mathrm{X}_{\text {tabel }}^{2}$ maka $\mathrm{H}_{0}$ diterima, sehingga dapat disimpulkan bahwa kelas eksperimen dan kelas kontrol berdistribusi normal.

Hasil homogenitas tes kemampuan pemecahan masalah matematis siswa dikelas eksperimen dan kelas kontrol dapat dilihat pada tabel 3 berikut ini:

Tabel 3. Uji Homogenitas Varians Data Hasil Post-test Kelas Sampel

\begin{tabular}{|c|c|c|c|c|c|}
\hline \multicolumn{2}{|c|}{ Varians } & \multirow[t]{2}{*}{$\alpha$} & \multirow[t]{2}{*}{ F $_{\text {hitung }}$} & \multirow[t]{2}{*}{$F_{\text {tabel }}$} & \multirow[t]{2}{*}{ Keterangan } \\
\hline Eksperimen & Kontrol & & & & \\
\hline 207,9364 & 112,4660 & 0,05 & 1,84 & 1,96 & Homogen \\
\hline
\end{tabular}

Pada $\alpha=5 \%$ dengan dk pembilang = na $-1=26-1=25$ dan dk penyebut $=\mathrm{nb}$ $-1=26-1=25$, maka didapat $\alpha$ (na$1) ;(n b-1)=1,96$ karena $F_{\text {hitung }}<F_{\text {tabel }}$ yaitu $1,84<1,96$, maka dapat disimpulkan bahwa kedua kelompok mempunyai varians yang sama (homogen) maka $\mathrm{H}_{0}$ diterima. 
Pengujian hipotesis ini dilakukan dengan uji t, karena data berdistribusi normal dan memiliki varians yang homogen. Hasil perhitungan uji hipotesis dapat dilihat pada tabel 4 berikut ini:

Tabel 4. Perbandingan Rata-rata Hasil Tes Kemampuan Pemecahan Masalah Matematis Siswa

\begin{tabular}{cccccc}
\hline Kelas & $\mathbf{N}$ & Rata-rata & $\mathbf{t}_{\text {hitung }}$ & $\mathbf{d k}$ & $\mathbf{t}_{\text {tabel }}$ \\
\hline Eksperimen & 26 & 76,92 & 2,56 & \multirow{2}{*}{50} & \multirow{2}{*}{1,68} \\
Kontrol & 26 & 67,93 & & & \\
\hline
\end{tabular}

Berdasarkan pada diatas diperoleh nilai $t_{\text {hitung }}=2,56$ lebih besar dari $t_{\text {tabel }}=$ 1,68 berarti $\mathrm{H}_{0}$ ditolak atau kemampuan pemecahan masalah matematis siswa yang dibelajarkan dengan model pembelajaran problem based learning (PBL) lebih tinggi dari pada kemampuan pemecahan masalah matematis siswa yang dibelajarkan dengan model pembelajaran langsung.

Pada penelitian ini terdapat satu kelas eksperimen yang di ajar dengan menggunakan model pembelajaran Problem Based Learning dan satu kelas kontrol yang diajar dengan menggunakan model pembelajaran langsung.Waktu pelaksanaan penelitian ini berlangsung selama 36 hari dengan intensitas pertemuan sebanyak tujuh kali di kelas eksperimen dan tujuh kali di kelas kontrol. Kedua kelas sampel diajar dengan materi yang sama tetapi berbeda pada penggunaan model pembelajaran yang diterapkan. Pada akhir penelitian kedua kelas sama-sama diberikan post-test untuk melihat hasil yang dicapai setelah pemberian perlakuan.

Berdasarkan post-test yang telah dilaksanakan terlihat bahwa kedua kelas menunjukkan hasil yang berbeda. Pada kelas eksperimen terlihat nilai rata-rata hasil belajar yang telah di capai sebesar 76,92 dan pada kelas kontrol terlihat nilai rata-rata hasil belajar sebesar 67,93. Dari hasil yang didapat maka terlihat bahwa hasil belajar yang dicapai memiliki perbedaan.Berdasarkan hasil perhitungan didapat kelas eksperimen mendapat nilai rata-rata lebih besar dari kelas kontrol.Hal ini terjadi karena beberapa faktor yang menjadi penyebab, diantaranya pada kelas ekperimen siswa yang diajarkan terlihat lebih aktif dan berperan besar dalam pembelajaran. Dalam pelaksanaan nya model pembelajaran Problem Based Learning diawali dengan pemberian rangsangan berpikir terlebih dahulu sebelum melaksanakan pembelajaran terkait dengan materi yang akan dipelajari dan masalah yang diberikan berkaitan dengan kehidupan siswa, dengan demikian siswa tidak terlalu mengalami kesulitan untuk mengimajinasikan masalah yang diberikan. Kemudian hal tersebut dapat memancing rasa ingin tahu siswa terhadap masalah yang diberikan.

\section{SIMPULAN DAN SARAN}

Rata-rata kemampuan pemecahan masalah matematis siswa pada materi SPLDV kelas eksperimen yang dibelajarkan dengan mengunakan model pembelajaran Problem Based Learning (PBL) memperoleh nilai rata-rata 76,92 dengan simpangan baku 14,42 dan kemampuan pemecahan masalah matematis siswa pada materi SPLDV kelas kontrol yang dibelajarkan dengan model pembelajaran langsung memperoleh nilai rata-rata 67,93 dengan simpangan baku 10,60. Hipotesisnya adalah Kriteria pengujian dari uji statistik dengan mengunakan uji-t, dimana diperoleh $t_{\text {hitung }}=2,56$ dan $t_{\text {tabel }}=1,68$. Sesuai dengan kriterian 
pengujian, jika $t_{\text {hitung }}>t_{\text {tabel }}$ maka $H_{1}$ diterima, terdapat perbedaan kemampuan pemecahan masalah pada materi SPLDV antar siswa yang mengunakan model pembelajaran Problem Based Learnig (PBL) dengan menggunakan model pembelajaran langsung. Ini berarti kemampuan pemecahan masalah siswa pada materi SPLDV yang dibelajarkan dengan mengunakan model pembelajaran problem based learnig (PBL) lebih tinggi dari pada pembelajaran menggunakan model pembelajaran langsung.

Untuk meningkatkan hasil belajar siswa di sekolah, sebaiknya menggunakan model pembelajaran Problem Based Learnig (PBL) dalam proses pembelajaran khususnya pelajaran matematika pokok bahasan SPLDV. Peneliti hanya melakukan penelitian pada satu pokok bahasan, peneliti berharap kepada peneliti selanjutnya jika ingin melakukan penelitian dilakukan pada pokok bahasan lainnya dan dapat membandingkan dengan model pembelajaran lain. Perlu adanya penelitian lebih lanjut sebagai pengembangan dari penelitian ini, terutama tentang hasil belajar matematika siswa.

\section{DAFTAR PUSTAKA}

Arikunto, Suharsimi. 2013. DasarDasar Evaluasi Pendidikan. Jakarta: Bumi Aksara

Firmansyah, Dani. 2015. Pengaruh Strategi Pembelajaran Dan Minat Belajar Terhadap hasil Belajar Matematika Jurnal Ilmiah Universitas Singaperbangsa Karawang

Sudjana. 2009. Metode Statistika. Bandung: Transito.
Sugiyono. 2011. Metode Penelitian Kuantitatif Kualitatif dan $R \& D$. Bandung: Alfabeta. 